\title{
Remediation of chromium contaminants using bacteria
}

\author{
P. Kanmani $\cdot$ J. Aravind $\cdot$ D. Preston
}

Received: 6 February 2011/Revised: 24 April 2011/Accepted: 25 August 2011/Published online: 26 November 2011

(c) CEERS, IAU 2011

\begin{abstract}
Chromium contaminants emanating from industrial activities pose a significant threat to human's wellbeing. Chromium (III) and Chromium (VI) are the forms in which they are commonly encountered, of which the trivalent form is relatively benign. Hence, biological reduction of hexavalent chromium has been widely explored by researchers, yielding fruitful outcomes, opening up exciting avenues and also throwing up new challenges. This article attempts to review this area of research. Microbes, especially bacteria capable of Chromium (VI) reduction, belonging to a heterogeneous group have been isolated from contaminated sites. They exhibit plasmid-mediated chromate resistance and the reduction is enzymatically mediated. Reduction studies have been carried out with free and immobilized enzymes as well as whole cells. Experiments have been carried out in specifically designed bioreactors operated in batch and continuous modes. Although significant progress has been made, much needs to be done for its successful in situ application as the organism may not withstand the Chromium concentration or may be impeded by the presence of other toxicants. With molecular engineering, it may be possible to derive strains with improved performance even under stressful field conditions.
\end{abstract}

Keywords Bioreduction - Biosorption · Chromate reductase - Chromium · Resistance . Toxicity

P. Kanmani $\cdot$ J. Aravind $(\bowtie)$

Department of Biotechnology, Kumaraguru College

of Technology, Coimbatore 641049, India

e-mail: aravindj@gmail.com

D. Preston

School of Biosciences and Technology, VIT University,

Vellore 632014, India

\section{Introduction}

Heavy metals that are frequently discharged in industrial effluents are of grave concern owing to their toxic effects. Chromium compounds find widespread industrial applications in electroplating, wood preservation, leather tanning and steel manufacturing sectors and subsequently end up as environmental contaminants.

\section{Chemistry of chromium}

Chromium is a steel-gray, lustrous, hard, brittle metal of Group VI-B of the transition series with atomic number of 24 and atomic weight of 51.996. It exists in a number of valence states ranging from -2 to +6 . However, $\mathrm{Cr}$ (III) and $\mathrm{Cr}(\mathrm{VI})$ are of significance owing to their stability in natural environments, although $\mathrm{Cr}$ with valences of I, II, IV and $\mathrm{V}$ have also been shown to exist in a number of compounds. The recommended permissible limit in drinking water is $50 \mu \mathrm{g} / \mathrm{L}$ for $\mathrm{Cr}(\mathrm{VI})$ (Krishnamurthy and Wilkens 1994).

\section{Transport and toxicity}

$\mathrm{Cr}$ (III) is an essential nutrient in this diet, aiding in the metabolism of glucose and lipids (Anderson 1997). However, ingesting large amounts of it may cause health problems including lung cancer (Katz and Salem 1994). $\mathrm{Cr}(\mathrm{VI})$ on the other hand is a potent, extremely toxic carcinogen and has been estimated to be 10-100 times more toxic than Cr(III) (Katz and Salem 1994). This may be due to the fact that $\mathrm{Cr}(\mathrm{VI})$ penetrates mammalian cells more readily than $\mathrm{Cr}(\mathrm{III})$. The United States Environmental 
Protection Agency (USEPA) determined its reference dose to be $1 \mathrm{mg} \mathrm{kg}^{-1}$ day $^{-1}$ (Katz and Salem 1994).

$\mathrm{Cr}(\mathrm{VI})$ enters the cell through the membrane sulphate transport channels (Ohtake and Silver 1994; Cervantes et al. 2000; Silver et al. 2001) and reacts with intracellular reductants such as glutathione and ascorbate. This generates short-lived intermediates $\mathrm{Cr}(\mathrm{V})$ and/or $\mathrm{Cr}(\mathrm{IV})$, free radicals and the end product $\mathrm{Cr}(\mathrm{III}) . \mathrm{Cr}(\mathrm{V})$ undergoes a one-electron redox cycle to regenerate $\mathrm{Cr}(\mathrm{VI})$ by transferring the electron to oxygen. This process results in the formation of reactive oxygen species (ROS) capable of combining with DNA-protein complexes (Fig. 1). Cr(IV) also binds to cellular materials and impedes their normal physiological functions (Pesti et al. 2000; Cervantes et al. 2000). Skin and nasal irritation, eardrum perforation and lung carcinoma are a few of the adverse effects linked with $\operatorname{Cr}(\mathrm{VI})$ (Gibb et al. 2000a, b). Apart from these, it can have teratogenic effects too (Saxena et al. 1990). Environmental effects include alteration in soil microbial communities and reduction in their growth and activity (Turpeinen et al. 2004). Hence, it becomes imperative to remove chromium contaminants, especially $\mathrm{Cr}(\mathrm{VI})$ from the environment.

Most of the intracellular $\mathrm{Cr}(\mathrm{VI})$ reductants are one electron reducers, which generate $\mathrm{Cr}(\mathrm{V})$ and result in the formation of ROS that are predominantly responsible for the adverse effects of $\mathrm{Cr}(\mathrm{VI})$ (modified from Cheung and Gu 2007).
Remediation of $\mathrm{Cr}$ contaminants: physico-chemical versus biological methods

Conventional chromium removal consists of chemical reduction followed by alkali precipitation or use of ion exchange and adsorption. The former technique generates large quantities of sludge while the latter are expensive and also less specific when other anions of heavy metals are present. Hence, attention has been shifted to biological methods of remediation. Biotransformation and biosorption are commonly used technologies, which utilize the potential of microorganisms or plants to transform or adsorb heavy metals. Of these, biotransformation (i.e. reduction of toxic, mobile $\mathrm{Cr}(\mathrm{VI})$ to less toxic, less mobile $\mathrm{Cr}(\mathrm{III})$ ) may be considered to be the better alternative. In biosorption, the contaminant gets accumulated in the biomass which again has to be disposed off, while in biotransformation, it is converted to an innocuous form. Under aerobic conditions, microbial chromate reduction is brought about by soluble reductases. In the absence of oxygen, both soluble and membrane bound reductases including cytochromes have been implicated. A large array of compounds including carbohydrates, proteins, fats, hydrogen, $\mathrm{NAD}(\mathrm{P}) \mathrm{H}$ and endogenous electron reserves can serve as electron donors in the reduction process (Wang 2000) (Fig. 2).

Under aerobic conditions, ChrR of Pseudomonas putida MK1 catalyzes one as well as two electron transfers to

Fig. 1 Schematic diagram of $\mathrm{Cr}(\mathrm{VI})$ transport into the cell and its fate

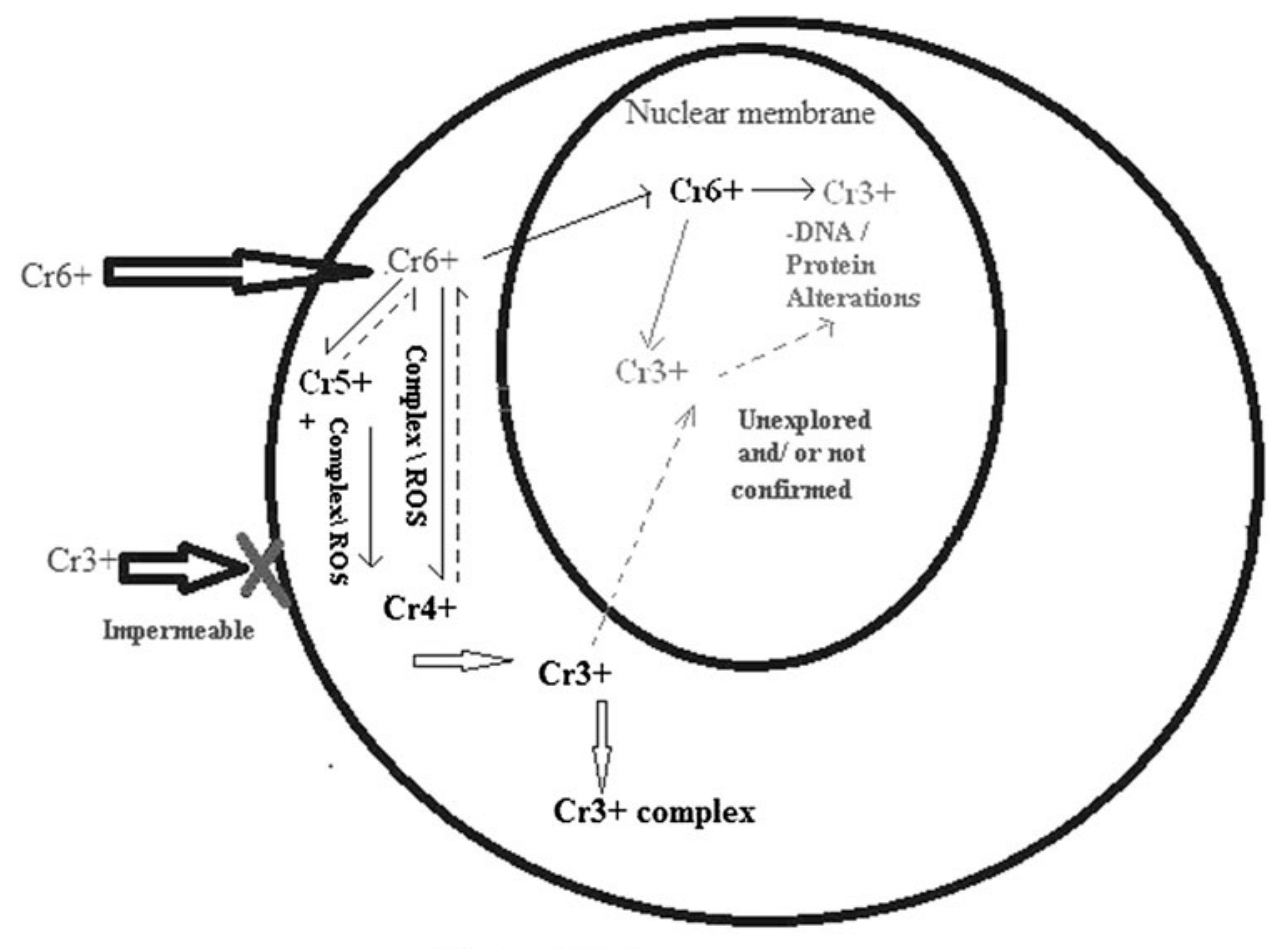

Bacterail Cell 
Fig. 2 Mechanisms likely to be involved in enzymatic reduction of $\mathrm{Cr}(\mathrm{VI})$ under aerobic and anaerobic conditions

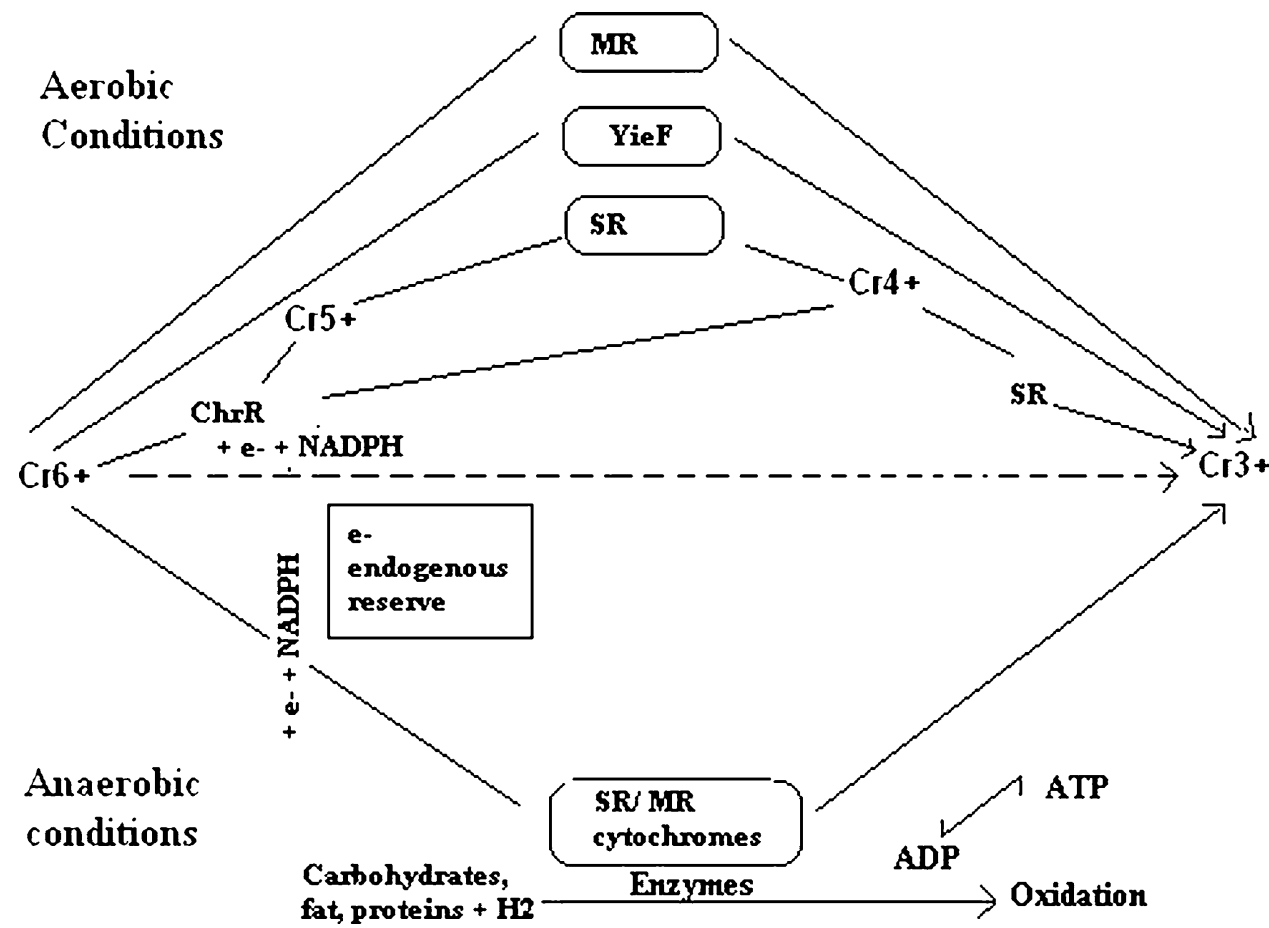

$\mathrm{Cr}(\mathrm{VI})$ with the transient formation of $\mathrm{Cr}(\mathrm{V})$, whereas $\mathrm{YieF}$ of Escherichia coli brings about a four electron transfer resulting in the direct reduction of $\mathrm{Cr}(\mathrm{VI})$ to $\mathrm{Cr}(\mathrm{III})$, with the remaining electron getting transferred to oxygen. A membrane-associated $\mathrm{Cr}^{+}$reductase isolated from Bacillus megaterium TKW3 has not been characterized. Under anaerobic conditions, both soluble and membrane-associated $\mathrm{Cr}(\mathrm{VI})$ reducing enzymes, including cytochromes, associated with the electron transfer system are involved (enzymes involved in the reduction of $\mathrm{Cr}(\mathrm{VI})$ are given in boxes, SR and MR represent soluble and membrane-associated reductases, respectively) (modified from Cheung and Gu 2007).

\section{Focus of this review}

This review broadly covers various aspects of $\mathrm{Cr}$ bioremediation, with the focus on bacteria-mediated $\mathrm{Cr}(\mathrm{VI})$ reduction, with more emphasis on recent findings. The genetic basis of $\mathrm{Cr}(\mathrm{VI})$ resistance which is plasmid rather than chromosome mediated and is attributed to reduced uptake, regulated efflux mechanisms or reduction along with parameters influencing the rate and extent of reduction by the isolates viz., temperature, $\mathrm{pH}$, availability of oxygen, initial $\mathrm{Cr}$ concentration, cell density, exogenous electron donors, presence of nitrates-sulphates, other heavy metals, have been discussed. Reduction potentials of growing cells, resting cells and cell-free supernatants have been compared; purification of chromate reductases and study of enzyme kinetics in case of free and immobilized systems have also been reviewed. $\mathrm{Cr}(\mathrm{VI})$ reduction by a few fungi and yeast has been briefly included for comparison sake.

\section{Bacterial $\mathrm{Cr}(\mathrm{VI})$ reduction}

Since the discovery of the first microbe $P$. dechromaticans capable of reducing $\mathrm{Cr}(\mathrm{VI})$ in the 1970s (Romanenko and Korenkov 1977), the search for chromate reducing microorganisms has continued and much information has been gathered on microbial-mediated $\mathrm{Cr}(\mathrm{VI})$ reduction, making its practical application feasible. $\mathrm{Cr}(\mathrm{VI})$-reducing bacteria belonging to diversified genera have been isolated from a variety of environments, indicating that such potential is widespread in nature and can be harnessed to facilitate remediation of $\mathrm{Cr}$ contaminated sites.

Among tannery isolates, Microbacterium sp. MP30 grew aerobically in a medium supplemented with $15 \mathrm{mM}$ chromate but did not reduce it. Under anaerobic conditions, it reduced $100 \mu \mathrm{M}$ sodium chromate within $30 \mathrm{~h}$ at the expense of acetate as electron donor (Pattanapipitpaisal et al. 2001). Moderately halophilic Nesterenkonia sp. MF2 was tolerant to a much higher concentration of $600 \mathrm{mM}$ chromate and completely reduced $200 \mu \mathrm{M} \mathrm{Cr}(\mathrm{VI})$ in $24 \mathrm{~h}$ under aerobic condition. Initial $\mathrm{Cr}(\mathrm{VI})$ concentration up to $400 \mu \mathrm{M}$ did not have a significant effect on $\mathrm{Cr}(\mathrm{VI})$ reduction. The isolate was capable of chromate reduction in the presence of various concentrations of salts (Amoozegar et al. 2007). A strain of B. circulans exhibited comparatively far better activity and reduced as much as 
$190 \mathrm{mM}$ chromate both under anaerobic and aerobic conditions, maximum reduction being observed at $28 \mathrm{~h}$ of incubation (Chaturvedi et al. 2007). Exiguobacterium sp. ZM-2 showed resistance to $12.37 \mathrm{mM}$ potassium chromate and reduced $500 \mu \mathrm{M} \mathrm{Cr}(\mathrm{VI})$ within $56 \mathrm{~h}$. The presence of metabolic inhibitors sodium azide and sodium cyanide severely affected chromate reduction, while 2, 4-dinitrophenol, and an uncoupling agent, stimulated chromate reduction (Alam and Malik 2008).

In one study using landfill isolates, Bacillus sp. XW-4 was tolerant to and reduced $1.9 \mathrm{mM} \mathrm{Cr}(\mathrm{VI})$. Chromate reduction by the strain was significantly enhanced by the presence of glucose (Liu et al. 2006). In another study, suspended cultures of $B$. cereus GIDM20, B. fusiformis GIDM22 and B. sphearicus GIDM64 exhibited more than $85 \%$ reduction of $1 \mathrm{mM} \mathrm{Cr}(\mathrm{VI})$ within $30 \mathrm{~h}$. The activity was found to be mainly associated with the soluble fraction of cells, expressed constitutively and unaffected by presence of different metal ions except $\mathrm{Hg}^{2+}$ and $\mathrm{Ag}^{+}$. Addition of NADH enhanced $\mathrm{Cr}(\mathrm{VI})$ reduction (Desai et al. 2008). Another bacterium, Ochrobactrum sp. showed $\mathrm{Cr}(\mathrm{VI})$ reduction ability under alkaline conditions. This isolate was tolerant to and reduced as much as $15.4 \mathrm{mM}$ $\mathrm{Cr}(\mathrm{VI})$. In this case too, the addition of glucose caused a dramatic increase in $\mathrm{Cr}(\mathrm{VI})$-reduction, while the presence of sulphate or nitrate had no influence (He et al. 2009). In another study, filamentous bacterium Sphaerotilus natans CSCr-3 isolated from activated sludge systems aerobically reduced up to $1.5 \mathrm{mM} \mathrm{Cr}(\mathrm{VI})$ in the presence of a carbon source (Caravelli et al. 2008). This reduction potential can be considered significant as $S$. natans is previously known only for its biosorption ability.

Bacillus sp. $\mathrm{KCH} 2$ and $\mathrm{KCH} 3$, Leucobacter $\mathrm{KCH} 4$ and Exiguobacterium $\mathrm{KCH} 5$ were isolated from $\mathrm{Cr}$ contaminated soil. Of these, $\mathrm{KCH} 3$ and $\mathrm{KCH} 4$ showed higher $\mathrm{Cr}(\mathrm{VI})$ tolerance $(2 \mathrm{mM})$ and reduction $(1.5 \mathrm{mM})$ than KCH5 (1.5 and $0.75 \mathrm{mM}$, respectively). $\mathrm{Cr}$ (VI) reduction was inhibited by $\mathrm{Hg}^{2+}$ and enhanced by $\mathrm{Cu}^{2+}$ (Sarangi and Krishnan 2008). Enriched cultures of indigenous bacteria isolated from a stream sediment contaminated by a pigment manufacturing industry reduced $31 \%$ of the $250 \mu \mathrm{M}$ $\mathrm{Cr}(\mathrm{VI})$, which is equivalent to the exchangeable $\mathrm{Cr}(\mathrm{VI})$ concentration in the sediment. The removal efficiency was increased with external supply of electron donor in the form of glucose, lactate or acetate (Lee et al. 2008).

During fermentative growth on D-xylose, isolates ES6 and WS01 (Cellulomonas) from US Department of Energy (DoE) Site decreased Cr(VI) concentrations from $0.04 \mathrm{mM}$ to below the detection limit $(0.002 \mathrm{mM})$ in less than 3 days and retained their ability to reduce $\mathrm{Cr}(\mathrm{VI})$ even after 4 months of incubation. Washed ES6 and WS01 cells also reduced $\mathrm{Cr}(\mathrm{VI})$ under non-growth conditions for over 4 months (Viamajala et al. 2007). Stimulation of such organisms may lead to effective long-term, in situ passive reactive barriers for $\mathrm{Cr}(\mathrm{VI})$ removal.

Staphylococcus epidermidis L-02 isolated from a bacterial consortium used for the remediation of a chromatecontaminated constructed wetland system reduced $\mathrm{Cr}(\mathrm{VI})$ by using pyruvate as an electron donor under anaerobic conditions. The presence of nitrate increased the specific reduction rate. Under denitrifying conditions, $\mathrm{Cr}(\mathrm{VI})$ reduction was not inhibited by nitrite. The maximum specific reduction rate was as high as $8.8-9.8 \mu \mathrm{M} \mathrm{Cr} 10^{10}$, cells/h (Vatsouria et al. 2005). Intrasporangium sp. Q5-1 isolated from a Mn/Cr contaminated site showed $17 \mathrm{mM} / \mathrm{L}$ minimum inhibitory concentration (MIC) for $\mathrm{Cr}(\mathrm{VI})$. Resting cells also reduced chromate. When immobilized with compounding beads containing 4\% Poly Vinyl Alcohol (PVA), 3\% sodium alginate, 1.5\% active carbon and $3 \%$ diatomite, the reduction rate remained unchanged (Yang et al. 2009). These immobilized cells have the advantage of stability, reusability and less clogging in continuous systems.

In an attempt to bring about $\mathrm{Cr}(\mathrm{VI})$ remediation using psychrophiles, core samples obtained from a $\mathrm{Cr}(\mathrm{VI})$ contaminated aquifer were enriched in Vogel Bonner medium supplemented with $\mathrm{Cr}(\mathrm{VI})$. The isolate Arthrobacter aurescens $\mathrm{P} 4$ was resistant to $19.2 \mathrm{mM} \mathrm{Cr}(\mathrm{VI})$ but reduction was slow or not observed at and above $1.9 \mathrm{mM} \mathrm{Cr}(\mathrm{VI})$ (Horton et al. 2006). This species has previously not shown to be capable of low temperature $\left(10^{\circ} \mathrm{C}\right) \mathrm{Cr}(\mathrm{VI})$ reduction.

Apart from such sites polluted by anthropogenic activities, chromate resistant bacteria have also been isolated from natural environments. B. sphearicus from naturally occurring chromium percolated soil of Andaman Islands was tolerant to $15.4 \mathrm{mM} \mathrm{Cr}(\mathrm{VI})$ and reduced $>80 \%$ of it during growth. Soluble fraction of the cell was responsible for aerobic reduction of chromate by this organism (Pal and Paul 2004). Burkholderia cepacia MCMB-821 isolated from the alkaline crater lake of Lonar was resistant to $19.2 \mathrm{mM} \mathrm{Cr}(\mathrm{VI})$ and reduced $98 \%$ of the $1.4 \mathrm{mM} \mathrm{Cr}(\mathrm{VI})$ within $36 \mathrm{~h}$ in the presence of $2 \%$ salt and lactose as the electron donor. Electron paramagnetic resonance (EPR) spectroscopy data suggested the formation of transient $\mathrm{Cr}(\mathrm{V})$ intermediate during reduction (Wani et al. 2007) (Table 1).

\section{Other novel findings}

In an endeavour to assess the toxic effect of chromate on soil microbial communities, soil microcosms were artificially contaminated with up to $1,000 \mathrm{mg} \mathrm{Cr}(\mathrm{VI}) / \mathrm{kg}$ soil. This affected the structure and diversity of the soil bacterial community. Bacterial strains isolated from the microcosm contaminated with highest concentration of chromate belonged to the genus Pseudomonas and no cyanobacterial 
Table 1 Chromate reduction potentials of various bacterial isolate

\begin{tabular}{|c|c|c|}
\hline Strain & $\begin{array}{l}\text { Chromate conc. the isolate is } \\
\text { capable of reducing }(\mathrm{mg} / \mathrm{L})\end{array}$ & References \\
\hline Microbacterium sp. MP-30 & $100 \mu \mathrm{M}$ & Pattanapipitpaisal et al. (2001) \\
\hline Thermus scotoductus SA-01 & $500 \mu \mathrm{M}$ & Opperman and Heerden (2007) \\
\hline Exiguobacterium sp. $\mathrm{KCH}-5$ & $0.75 \mathrm{mM}$ & Sarangi and Krishnan (2008) \\
\hline $\begin{array}{l}\text { Bacillus sp. } \mathrm{KCH}-3 \text {, } \\
\text { Leucobacter } \mathrm{KCH}-4\end{array}$ & $1.5 \mathrm{mM}$ & Sarangi and Krishnan (2008) \\
\hline Sphearotilus natans & $1.5 \mathrm{mM}$ & Caravelli et al. (2008) \\
\hline Arthrobacter aurescens $\mathrm{P} 4$ & $1.9 \mathrm{mM}$ & Horton et al. (2006) \\
\hline Ochrobactrum sp. CSCr-3 & $15.3 \mathrm{M}$ & He et al. (2009) \\
\hline
\end{tabular}

growth was detected in this, indicating their sensitivity. Some enzymes were inhibited, others stimulated and the ATP content in microcosms was strongly affected by chromate (Viti et al. 2006). Thus, the soil microbial community responds to chromate pollution through changes in community structure, in metabolic activity, and in selection for $\mathrm{Cr}(\mathrm{VI})$-resistance.

$\mathrm{Cr}(\mathrm{VI})$ is usually known to be reduced to $\mathrm{Cr}(\mathrm{III})$. However, as a rare occurrence, Shewanella oneidensis, reduced $\mathrm{Cr}(\mathrm{VI})$ to $\mathrm{Cr}(\mathrm{II})$. Individual cell microanalysis demonstrated that the $\mathrm{Cr}$ (II) concentrated near the cytoplasmic membrane, suggesting intracellular localization of the terminal reduction pathway (Daulton et al. 2007).

Acetate was added to aid in the bioremediation of two closed soil-water systems representative of the subsurface environment close to chromium ore processing residue disposal sites; one had a $\mathrm{pH}$ of 7.7, the other 9.3. $\mathrm{Cr}(\mathrm{VI})$ reduction occurred in both systems as part of a cascade of microbially mediated terminal electron-accepting processes, occurring between nitrate and iron reduction. $\mathrm{Cr}(\mathrm{VI})$ and subsequently iron reduction took longer to start and were slower in the more alkaline system. At the point when $\mathrm{Cr}(\mathrm{VI})$ reduction was essentially complete, the microbial populations in both systems showed an increase in species closely related to $\beta$-proteobacteria that are capable of nitrate reduction (Stewart et al. 2007).

$\mathrm{Cr}(\mathrm{III})$ produced as a result of $\mathrm{Cr}(\mathrm{VI})$ reduction is mostly considered to be insoluble $\mathrm{Cr}(\mathrm{OH})_{3}$. However, $\mathrm{Cr}(\mathrm{VI})$ reduction in the presence of cellular organic metabolites formed both soluble and insoluble organo$\mathrm{Cr}$ (III) end-products (Puzon et al. 2005). These organo$\mathrm{Cr}$ (III) complexes may account for the mobile form of $\mathrm{Cr}(\mathrm{III})$ detected in the environment. Such soluble complexes have been demonstrated with four bacterial cultures (S. oneidensis MR1, Cellulomonas sp. ES6, Rhodococcus sp. and Desulfovibrio vulgaris var Hildenborough). Structural characterization of the complexes indicated that they were composed of multiple chromium ions bound together by the cellular metabolites (Puzon et al. 2008).
A better understanding of the organo-Cr(III) pathway will be useful in designing remediation strategies for $\mathrm{Cr}$ impacted soils.

The shape of Leucobacter $\mathrm{Ch} 1$ cells before and after chromate reduction was observed using scanning and transmission electron microscopy. The composition of reduction products was determined using Energy Dispersive X-ray Analysis and EPR Spectroscopy and was found to contain $28.2 \% \mathrm{Cr}$ in the form of $\mathrm{Cr}(\mathrm{OH})_{3}$ precipitate (Zhu et al. 2008).

$\mathrm{Cr}(\mathrm{VI})$ migrating downwards from a chromium ore processing residue was of concern because groundwater emerging from the site was alkaline, visibly yellow and had an elevated $\mathrm{Cr}(\mathrm{VI})$ concentration. Sandy clay from immediately beneath the waste contained up to $3,000 \mathrm{mg} / \mathrm{kg}$ of $\mathrm{Cr}$, and around $60 \%$ of $0.5 \mathrm{~N} \mathrm{HCl}$ extractable iron in the form of reduced $\mathrm{Fe}(\mathrm{II})$. Very recent microcosm experiments showed that the soil contained a viable bacterial population capable of iron-reduction. This sandy clay layer, despite a $\mathrm{pH}$ value of 10.5 , acted as a natural reactive zone beneath the waste as it accumulated chromium (Stewart et al. 2010). The mechanism of $\mathrm{Cr}(\mathrm{VI})$ reduction is believed, most likely to be an abiotic reaction with the $\mathrm{Fe}(\mathrm{II})$ present in the soil, and the $\mathrm{Fe}(\mathrm{II})$ being replenished by microbial iron-reduction.

Purification and characterization of bacterial chromate reductases

Chromate reductases have been purified and characterized by several researchers. Cloning the genes that encode chromate reductases can result in further advancements in bioremediation. Characterization of chromate reduction by a flavin reductase from E. coli revealed faster reduction when compared to chemical reduction by NADH and glutathione suggesting that unlike eukaryotes, enzymatic reduction is the dominant mechanism in bacterial cells (Puzon et al. 2002). Chromate reductase encoding genes vary according to the microorganism and also occurs in 
plasmids, few literatures are available describing the gene sequence (Barak et al. 2006; Gonzalez et al. 2005).

A soluble $\mathrm{Cr}(\mathrm{VI})$ reductase purified from the cytoplasm of E. coli ATCC 33456 was a dimmer with a molecular mass of $84 \mathrm{kDa}$. The pI was 4.66 , and optimal enzyme activity was obtained at $\mathrm{pH} 6.5$ and $37^{\circ} \mathrm{C}$. The purified enzyme used both NADPH and NADH as electron donors for $\mathrm{Cr}(\mathrm{VI})$ reduction, while NADPH was the better, conferring $61 \%$ higher activity than NADH. The $K_{\mathrm{m}}$ values for NADPH and NADH were 47.5 and $17.2 \mu \mathrm{mol}$, and the $V_{\max }$ values 322.2 and $130.7 \mu \mathrm{mol} \mathrm{Cr}(\mathrm{VI}) \mathrm{min} / \mathrm{mg}$ protein, respectively. The activity was strongly inhibited by $N$-ethylmalemide, $\mathrm{Ag}^{2+}, \mathrm{Cd}^{2+}, \mathrm{Hg}^{2+}$ and $\mathrm{Zn}^{2+}$ (Bae et al. 2005)

Chromate reductase from $P$. putida was purified by $\left[\mathrm{NH}_{4}\right]_{2} \mathrm{SO}_{4}$ precipitation, anion exchange (DEAE sepharose CL-6B) and gel filtration (Sephadex-G-25) chromatography. The enzyme activity was dependent on NADH or $\mathrm{NADPH}$, the temperature and $\mathrm{pH}$ optima were $75^{\circ} \mathrm{C}$ and 8.5 , respectively, and the $K_{\mathrm{m}}$ was $260 \mu \mathrm{M}$ with a $V_{\max }$ of $8.8 \mu \mathrm{mol} / \mathrm{min} / \mathrm{mg}$ of protein. It had a molecular weight of $20 \mathrm{KDa}$ (Renuga et al. 2008).

Thermus scotoductus SA-01, a South African gold mine isolate reduced $\mathrm{Cr}(\mathrm{VI})$ when grown aerobically in an organic medium containing $0.5 \mathrm{mM} \mathrm{Cr}(\mathrm{VI})$ (Opperman and Heerden 2007). Cell suspensions also reduced $\mathrm{Cr}(\mathrm{VI})$ under non-growth conditions. The reduction was found to be catalysed by a cytoplasmic, constitutively expressed enzyme. This enzyme was purified to homogeneity and was found to be a homodimeric protein, with a monomer molecular mass of $36 \mathrm{kDa}$, containing a non-covalently bound Flavin Mononucleotide cofactor. Enzyme activity was dependent on NADH or NADPH, with a preference for NADPH. The catalytic efficiency of chromate reduction was 50-fold greater than that of the quinone reductases and 180 -fold more efficient than that of the nitroreductases. It was encoded by an open reading frame (ORF) of 1,050 bp, and was under the regulation of an E. coli $\sigma^{70}$-like promoter (Opperman and Heerden 2008). T. scotoductus also has a second strictly anaerobic membrane bound enzyme capable of chromate reduction. This enzyme showed a preference towards NADH. It was also a homodimer, but with a monomeric molecular weight of $48 \mathrm{kDa}$ and a noncovalently bound FAD coenzyme. The catalytic efficiency of this enzyme was comparable to that of quinone reductases but more efficient than the nitroreductases. N-terminal sequencing and subsequent screening of a genomic library of T. scotoductus revealed an ORF of 1,386 bp, homologous (84\%) to the dihydrolipoamide dehydrogenase gene of T. thermophilus HB8 (Opperman et al. 2008). These results extend the knowledge of chromate reductases mediating $\mathrm{Cr}(\mathrm{VI})$ reduction via noncovalently bound or free redox-active flavin groups and the activity of dihydrolipoamide dehydrogenases towards physiologically unrelated substrates.

The kinetics of enzymatic reduction has also been studied using immobilized enzyme systems. In a recent work, chromate reductases associated with cell-free extracts of $A$. rhombi-RE were immobilized with different matrices and calcium alginate beads proved to be most effective (Elangovan et al. 2010). However, the performance was not encouraging under continuous mode of operation (Table 2).

\section{Bioreactor studies for bacterial $\mathrm{Cr}(\mathrm{VI})$ remediation}

Membrane bioreactors have been used in order to minimize the toxic effects of $\mathrm{Cr}(\mathrm{VI})$ on microorganisms or to facilitate the isolation of chromium that is reduced. Immobilized cells have also been used in such membrane reactors. One example is the use of Pseudomonas immobilized on agar-agar films for chromate reduction (Konovalova et al. 2003).

The relationship between sulphate starvation and chromate reduction was studied in a $\mathrm{H}_{2}$-fed fixed-film bioreactor under continuous feed conditions. The bioreactor was inoculated with a bacterial consortium containing Desulfomicrobium norvegicum. With $500 \mathrm{mg} / \mathrm{L}$ of sulphate in the feed solution, total chromate-reduction was observed in the effluent whereas sulphate-reduction was strongly decreased. In the absence of sulphate, chromate-reduction activity was still observed but was lower than in the presence of sulphate.

In another study, columns packed with quartz sand alone and hydrous ferric oxide (HFO)-coated quartz sand were inoculated with Cellulomonas sp. ES6, fed nutrients to stimulate growth and then nutrient-free $\mathrm{Cr}(\mathrm{VI})$ solutions were injected into the column. In HFO-containing columns, $\mathrm{Cr}(\mathrm{VI})$ reduction was significantly prolonged and effluent $\mathrm{Cr}(\mathrm{VI})$ concentrations remained below detectable levels for periods of up to 66 residence times after nutrient injection was discontinued as against 5.7 residence times for columns packed with quartz sand alone. Fe was continuously detected in the effluent indicating that the insoluble $\mathrm{Fe}(\mathrm{III})$ bearing solids were being reduced to form soluble $\mathrm{Fe}(\mathrm{II})$ resulting in prolonged abiotic $\mathrm{Cr}(\mathrm{VI})$ reduction (Viamajala et al. 2008). Thus, growth of Cellulomonas resulted in formation of permeable reactive barriers that could reduce $\mathrm{Cr}(\mathrm{VI})$ and $\mathrm{Fe}(\mathrm{III})$ for extended periods even in the absence of external electron donors. This may be a viable technology for in situ remediation of $\mathrm{Cr}(\mathrm{VI})$-contaminated groundwater.

Chromate reduction by Arthrobacter CR47 isolated from a landfarming soil sample was studied in batch operated packed bed biofilm reactors and in recirculating packed bed biofilm reactors. The reduction was evaluated 
Table 2 Characterization of chromate reductases from a few bacteria

\begin{tabular}{|c|c|c|c|c|c|c|}
\hline $\begin{array}{l}\text { Bacteria from which the } \\
\text { chromate reductase is purified }\end{array}$ & $\begin{array}{l}\text { Mol. } \\
\text { Wt. } \\
(\mathrm{kDa})\end{array}$ & $\begin{array}{l}\text { Temp. } \\
\text { optima } \\
\left({ }^{\circ} \mathrm{C}\right)\end{array}$ & $\begin{array}{l}\mathrm{pH} \\
\text { optima }\end{array}$ & $K_{\mathrm{M}}$ & $\begin{array}{l}V_{\max }(\mathrm{Cr}(\mathrm{VI}) \\
\text { reduced/ } \\
\text { min/mg protein })\end{array}$ & References \\
\hline Bacillus sp. QC1-2 & 44 & 37 & 7 & $0.35 \mathrm{mM}$ & $50 \mathrm{nM}$ & Garcia et al. (1997) \\
\hline E. coli ATCC 33456 & 84 & 37 & 6.5 & $47.5 \mu \mathrm{M}$ & $322 \mu \mathrm{M}$ & Bae et al. (2005) \\
\hline Pseudomonas putida & 20 & 75 & 8.5 & $260 \mu \mathrm{M}$ & $8.8 \mu \mathrm{M}$ & Renuga et al. (2008) \\
\hline Thermus scotoductus SA-01 (soluble reductases) & 72 & 65 & 6.3 & $8.4 \mu \mathrm{M}$ & $16 \mu \mathrm{M}$ & $\begin{array}{l}\text { Opperman and Heerden } \\
\text { (2008) }\end{array}$ \\
\hline $\begin{array}{l}\text { Thermus scotoductus SA-01 (membrane bound } \\
\text { reductase) }\end{array}$ & 96 & 65 & 6.5 & $55.5 \mu \mathrm{M}$ & $23 \mu \mathrm{M}$ & Opperman et al. (2008) \\
\hline Exiguobacterium sp. ZM-2 & - & - & - & $106.1 \mu \mathrm{M}$ & $1.24 \mu \mathrm{M}$ & Alam and Malik (2008) \\
\hline Bacillus sp. KCH-3, & - & 35 & 5.5 & $45-55 \mu \mathrm{M}$ & - & $\begin{array}{l}\text { Sarangi and Krishnan } \\
\text { (2008) }\end{array}$ \\
\hline Leucobacter $\mathrm{KCH}-4$ & - & 30 & 5.5 & $45-55 \mu \mathrm{M}$ & - & $\begin{array}{l}\text { Sarangi and Krishnan } \\
\text { (2008) }\end{array}$ \\
\hline Exiguobacterium sp. KCH-5 & - & 35 & 6 & $200 \mu \mathrm{M}$ & - & $\begin{array}{l}\text { Sarangi and Krishnan } \\
\text { (2008) }\end{array}$ \\
\hline Bacillus sp. GIDM-22 & - & - & - & $200 \mu \mathrm{M}$ & $5.5 \mu \mathrm{M}$ & Desai et al. (2008) \\
\hline Arthrobacter rhombi-RE & - & 30 & 5.5 & $48 \mu \mathrm{M}$ & $4.09 \mathrm{nM}$ & Elangovan et al. (2010) \\
\hline
\end{tabular}

with laboratory solutions and industrial effluents containing $30 \mathrm{mg} / \mathrm{L} \mathrm{Cr}(\mathrm{VI})$. Under batch mode, the reduction reaction by the biofilm fit an exponential-decay model with a first order kinetic parameter of $0.071 \mathrm{mg}(\mathrm{L} / \mathrm{h})$ $\mathrm{Cr}(\mathrm{VI})$. In the recirculating reactor fed with laboratory solutions, the removal rate was $0.79 \mathrm{mg} / \mathrm{L} / \mathrm{h}$. In the reactor fed with the industrial model solutions, the maximum $\mathrm{Cr}(\mathrm{VI})$ removal rate attained was $0.49 \mathrm{mg} / \mathrm{L} / \mathrm{h}$ (Cordoba et al. 2008).

In yet another attempt, chromate reduction was carried out in a pilot-scale trickling filter packed with plastic media under continuous mode of operation with recirculation. Mixed bacterial cultures originated from industrial sludge were used for this study. The effect of the organic carbon concentration was examined for constant $\mathrm{Cr}$ (VI) influent concentration at about $5.5 \mathrm{mg} / \mathrm{L}$ and volumetric flow rates ranging from 60 to $900 \mathrm{~mL} / \mathrm{min}$. The highest reduction rate achieved was $1,117 \mathrm{~g} \mathrm{Cr}(\mathrm{VI}) / \mathrm{m}^{2} /$ day for a volumetric flow rate of $900 \mathrm{~mL} / \mathrm{min}$ (Dermou and Vayenas 2008). Even though the system mandated frequent backwashing of the filter, the high reduction rates combined with low operating cost make this an option worth considering for the treatment of industrial chromate effluents.

Recently, activated sludge process was used for continuous $\mathrm{Cr}(\mathrm{VI})$ removal and the highest specific $\mathrm{Cr}(\mathrm{VI})$ removal rate was attained with cheese whey or lactose as electron donors. Batch assays with different nitrogen to carbon source ratios demonstrated that $\mathrm{Cr}(\mathrm{VI})$ reduction was associated with the cell multiplication phase; as a result, maximum removal occurred when there was no substrate limitation (Orozco et al. 2010).

\section{Bacterial Cr(VI) resistance}

$\mathrm{Cr}(\mathrm{VI})$ resistant bacteria have been isolated from a number of environments and the genetic basis of resistance has been studied. Such studies have abundantly been carried out with tannery isolates. In one such work, among several isolates, all of which harboured plasmid DNA, Corynebacterium hoagie showed maximal resistance to $22 \mathrm{mM}$ Cr(VI) (Viti et al. 2003). Thermotolerant strains resistant to $\mathrm{Cr}$ too have been isolated from tannery sources. These plasmid bearing isolates showed resistance to other heavy metals and antibiotics as well, which make them particularly useful. Three of the isolates belonged to uropathogenic E. coli serotype 04 (Verma et al. 2004). In another study, B. brevis showed good plasmid-mediated resistance and reduction potential as established by transfer and curing studies (Verma et al. 2009).

Enterobacter cloacae CYS-25, isolated from a chromate plant showed a strong tendency for chromate resistance due to reduced uptake and not reduction. Atomic force microscopic investigation showed that the average length of the bacterium in the stationary phase is about $2.3 \pm 0.6 \mu \mathrm{M}$, while under the stimulation of $400 \mathrm{mg} / \mathrm{L} \mathrm{CrO}_{4}{ }^{2-}$, the length increased to $3.2 \pm 0.7 \mu \mathrm{M}$. Moreover, the smooth surface of the bacterium changed into one with discontinuous features. These compact convex patches are organic components stimulated by $\mathrm{CrO}_{4}{ }^{2-}$ (Yang et al. 2007). 
Hence, an over expression of extracellular biological components for preventing the permeability of $\mathrm{CrO}_{4}{ }^{2-}$ into the cell helps the bacteria to survive chromate stress.

DNA helicases are involved in chromate resistance by $P$. aeruginosa PAO1. Chromate-hypersensitive mutants were generated using transposon insertion mutagenesis. Comparison of the nucleotide sequences of the regions interrupted within the PAO1 genome showed that mutant strains were affected in ORF PA0967 and PA5345, which correspond to the ruvB and recG genes, respectively. These genes encode helicases RuvB and RecG involved in DNA replication, recombination and repair. The chromate resistance phenotype was restored by cosmids bearing wild type ruvB or recG genes (Miranda et al. 2009). P. aeruginosa RuvB and RecG helicases are thus involved in repairing DNA damage caused by chromate.

The genome of Arthrobacter sp. FB24 is known to contain a chromate resistance determinant (CRD), consisting of a cluster of eight genes located on a $10.6 \mathrm{~kb}$ fragment of a $96 \mathrm{~kb}$ plasmid. The CRD includes chrA, which encodes a putative chromate efflux protein, and three genes with amino acid similarities to the amino and carboxyl termini of $\mathrm{ChrB}$, a putative regulatory protein. There are also three novel genes that have not been previously associated with chromate resistance; they encode an oxidoreductase (most similar to malate:quinone oxidoreductase), a functionally unknown protein with a WD40 repeat domain and a lipoprotein. In one study, chromate-sensitive mutant (strain D11) of this bacterium was generated by curing FB24 of its $96-\mathrm{kb}$ plasmid. The mutants accumulated three times more chromium than wild type cells. Introduction of the CRD into strain D11 conferred chromate resistance comparable to wild-type levels, whereas deletion of specific regions of the CRD led to decreased resistance. Using real-time reverse transcriptase PCR, the expression of each gene within the CRD was shown to be specifically induced in response to chromate. Higher levels of chrA expression were achieved when the chrB orthologs and the WD40 repeat domain genes were present, suggesting their possible regulatory roles (Henne et al. 2009). These findings indicate that chromate resistance in Arthrobacter FB24 is due to chromate efflux through the ChrA transport protein (Table 3).

$\mathrm{Cr}(\mathrm{VI})$ reduction by fungi, yeast and actinomycetes

Although a wide variety of bacterial cultures have been reported for their capability to reduce $\mathrm{Cr}(\mathrm{VI})$, little information exists on filamentous fungi (Pal. 1997) and yeasts (Muter et al. 2001; Ramirez-Ramirez et al. 2004). One such study was the $\mathrm{Cr}(\mathrm{VI})$ reduction by Trichoderma viride in stirred tank and concentric tube airlift bioreactors. The
Table 3 Chromate resistance of bacterial isolates

\begin{tabular}{|c|c|c|}
\hline Strain & $\begin{array}{l}\text { Chromate conc. to } \\
\text { which } \\
\text { the isolate is resistant }\end{array}$ & References \\
\hline Bacillus brevis & $180 \mu \mathrm{M}$ & Verma et al. (2009) \\
\hline $\begin{array}{l}\text { Exiguobacterium } \\
\text { sp. KCH-5 }\end{array}$ & $1.5 \mathrm{mM}$ & $\begin{array}{l}\text { Sarangi and } \\
\text { Krishnan } \\
(2008)\end{array}$ \\
\hline Bacillus sphearicus & $15.3 \mathrm{mM}$ & Pal and Paul (2004) \\
\hline $\begin{array}{l}\text { Ochrobactrum sp. } \\
\text { CSCr-3 }\end{array}$ & $15.3 \mathrm{mM}$ & He et al. (2009) \\
\hline $\begin{array}{l}\text { Arthrobacter } \\
\text { aurescens } \mathrm{P} 4\end{array}$ & $19.2 \mathrm{mM}$ & Horton et al. (2006) \\
\hline $\begin{array}{l}\text { Bacillus circulans } \\
\text { MNI }\end{array}$ & $19.2 \mathrm{mM}$ & $\begin{array}{l}\text { Chaturvedi et al. } \\
\text { (2007) }\end{array}$ \\
\hline $\begin{array}{l}\text { Burkholderia cepacia } \\
\text { sp. MCMB-821 }\end{array}$ & $19.2 \mathrm{mM}$ & Wani et al. (2007) \\
\hline $\begin{array}{l}\text { Nesterenkonia sp. } \\
\text { MF-2 }\end{array}$ & $600 \mathrm{mM}$ & $\begin{array}{l}\text { Amoozegar et al. } \\
(2007)\end{array}$ \\
\hline
\end{tabular}

airlift reactor performed better because the agitation in stirred tank bioreactor inflicted physical damage on the mycelia, causing their defragmentation (Morales-Barrera and Cristiani-Urbina 2005). Lecythophora sp. NGV-1, Candida sp. NGV-9 and Aureobasidium pullulans VR-8 isolated from tannery effluents and from a nickel-copper mine in Argentina showed tolerance to multiple heavy metals including $\mathrm{Cr}(\mathrm{VI})$. Growth in YNB-glucose medium supplemented with 0.5 and $1 \mathrm{mM} \mathrm{Cr}(\mathrm{VI})$ revealed that resistance was mainly due to reduction rather than bioaccumulation (Villegas et al. 2008).

Actinomycetes have also been screened for chromate reduction. Streptomyces griseus NCIM 2020 reduced $\mathrm{Cr}(\mathrm{VI})$ at the expense of a variety of electron donors. Sulphate, nitrate, chloride and carbonate had no effect on chromate reduction while cations such as $\mathrm{Cd}, \mathrm{Ni}, \mathrm{Co}$ and $\mathrm{Cu}$ were inhibitory. Cell-free extracts also reduced chromate and addition of $\mathrm{NAD}(\mathrm{P}) \mathrm{H}$ resulted in two- to threefold increase in activity. Sonication was the best method to release the chromate reductase expressed constitutively. The enzyme showed optimum activity at $28^{\circ} \mathrm{C}$ and $\mathrm{pH} 7$ (Poopal and Laxman 2009a). Different matrices were tested for whole cell immobilization of this chromate-reducing organism and PVA-alginate was found to be the most effective and was used in a bioreactor. $\mathrm{Cr}(\mathrm{VI})$ reduction efficiency decreased as $\mathrm{Cr}(\mathrm{VI})$ was increased from 2 to $12 \mathrm{mg} / \mathrm{L}$ but increased with an increase in biomass concentration. However, increasing the flow rate from 2 to $8 \mathrm{ml} / \mathrm{h}$ did not significantly affect $\mathrm{Cr}(\mathrm{VI})$ reduction (Poopal and Laxman 2009b). Such immobilized S. griseus cells could be applied for large-scale bioremediation of chromate-containing wastewaters. 
Chromium biosorption

Several biosorption studies have also been carried out for $\mathrm{Cr}$. Although voluminous research has been carried out on this front, this paper takes only a fleeting glance at it, confining itself largely to biological reduction. Microorganisms such as bacteria (Srinath et al. 2002), fungi (Bai and Abraham 2003) and algae (Aravindhan et al. 2004) have been used in biosorption studies. The bacterium $P$. aeruginosa (Kang et al. 2006) fungus Mucor hiemalis (Tewari et al. 2005), yeast Pichia guilliermondi (Kaszycki et al. 2004) and microalgae Scenedesmus incrassatulus (Pena-Castro et al. 2004) are a few examples of organisms whose metal-binding capacities have been demonstrated.

As biosorption of metals using living biomass is timeconsuming and it is expensive to find appropriate biomass, research interest turned to the use of dead microbial biomass and other biomaterials which are of low cost and are abundant. The removal of heavy metals by biomass by-products from agricultural, industrial or pharmaceutical industry has proved to be highly efficient. These biomaterials are of little commercial value and serve as substitutes for more expensive sources. They possess large quantity of adsorption sites (Law et al. 2003; Tarley and Arruda 2004) and functional groups for ion-exchange such as hydroxyl, carboxyl and phosphate groups as revealed by Fourier transform infrared spectrum (Law et al. 2003; Tarley and Arruda 2004; Chen et al. 2005). Cone biomass of Pinus sylvestris showed biosorption ability for $\mathrm{Cr}(\mathrm{VI})$ (Ucun et al. 2002). The agricultural biomass by-product Lentinus edodes also exhibited $\mathrm{Cr}(\mathrm{VI})$ biosorption potential. Nitrogen oxides and carboxyl groups were increased after adsorption and cation exchange was the underlying mechanism (Chen et al. 2006).

In another interesting revelation, chromate-tolerant bacteria isolated from the rhizosphere of aquatic plant Eichhornia crassipes enhanced $\mathrm{Cr}$ uptake by the plant. Plants inoculated with RA1 (P. diminuta), RA2 (Brevundimonas diminuta), RA3 (Nitrobacteria irancium), RA5 (Ochrobactrum anthropi), RA7 and RA8 (B. cereus) had 7-, 11-, 24-, 29-, 35- and 21-fold, respectively, higher $\mathrm{Cr}$ concentrations in roots compared to the control (AbouShanab et al. 2007). These bacterial isolates can play a supportive role in phytoremediation of $\mathrm{Cr}$ contaminants.

\section{Conclusion}

Bacterial reduction of hexavalent $\mathrm{Cr}$ to its trivalent form is an option worth exploring for the remediation of diverse chromium contaminated sites. Its advantages over physical-chemical treatments are innumerable and research in this direction has come out with promising findings. Yet, large scale field application of this technology warrants an improved understanding of the mechanisms involved in resistance and reduction of $\mathrm{Cr}(\mathrm{VI})$. Application of genetic and protein engineering tools to broaden enzyme activity should also be further researched. Enzyme purification, characterization and cloning of genes encoding chromate reductases are prerequisites for this, areas in which work has progressed well. Furthermore, successful implementation of a bioremediation program necessitates a thorough assessment of the contaminated site and choice of an appropriate technology as well as microbial strain that is best suited for the prevailing conditions.

\section{References}

Abou-Shanab RAI, Angle JS, Van Berkum P (2007) Chromatetolerant bacteria for enhanced metal uptake by Eichhornia crassipes (MART). Int J Phytorem 9(2):91-105

Alam MZ, Malik A (2008) Chromate resistance, transport and bioreduction by Exiguobacterium sp. ZM-2 isolated from agricultural soil irrigated with tannery effluent. J Basic Microbiol 48(5):416-420

Amoozegar MA, Ghasemi A, Razavi MR, Naddaf S (2007) Evaluation of Hexavalent chromium reduction by chromate resistant moderate halophile Nesterenkonia sp. strain MF2. Process Biochem 42(10):1475-1479

Anderson RA (1997) Chromium as an essential nutrient for humans. Regul Toxicol Pharmacol 26:S35-S41

Aravindhan R, Madhan B, Rao JR (2004) Bioaccumulation of chromium from tannery wastewater: an approach for chrome recovery and reuse. Environ Sci Technol 38:300-306

Bae WC, Lee HK, Choe YC, Jahng DJ, Lee SH, Kim SJ, Lee JH, Jeong BC (2005) Purification and characterization of NADPHdependent $\mathrm{Cr}(\mathrm{VI})$ reductase from Escherichia coli ATCC 33456. J Microbiol 43(1):21-27

Bai RS, Abraham TE (2003) Studies on Chromium(VI) adsorptiondesorption using immobilized fungal biomass. Bioresour Technol 87:17-26

Barak Y, Ackerley DF, Dodge CJ, Banwari L, Alex C, Francis AJ, Matin A (2006) Analysis of novel soluble chromate and uranyl reductase and generation of an improved enzyme by directed evolution. Appl Environ Microbiol 72(11):7074-7082

Caravelli AH, Giannuzzi L, Zaritzky NE (2008) Reduction of hexavalent chromium by Spaerotilus natans a filamentous microorganism present in activated sludges. J Hazard Mater 156(1-3):214-222

Cervantes C, Campos-Garcia J, Devars S, Gutierrez-Corona F, LozaTavera H, Torres-Guzman JC, Moreno-Sanchez R (2000) Interactions of chromium. Am J Ind Med 38:127-131

Chaturvedi MK, Bhatt S, Shukla NP (2007) Hexavalent chromium removal under anaerobic and aerobic conditions by Bacillus circulans strain MNI. Pollut Res 26(1):5-11

Chen GQ, Zeng GM, Tu X (2005) A novel biosorbent: characterization of the spent mushroom compost and its application for removal of heavy metals. J Environ Sci 17:756-760

Chen GQ, Zeng GM, Tu X, Niu CG, Huang GH, Jiang W (2006) Application of a by-product of Lentinus edodes to the bioremediation of chromate contaminated water. J Hazard Mater 135(1-3):249-255 
Cheung KH, Gu J (2007) Mechanism of hexavalent chromium detoxification by microorganisms and bioremediation application potential: a review. Int Biodeter Biodegr 59:8-15

Cordoba A, Vargas P, Dussan J (2008) Chromate reduction by Arthrobacter CR47 in biofilm packed bed reactors. J Hazard Mater 151(1):274-279

Daulton TL, Little BJ, Meehan J, Blom DA, Allard LF (2007) Microbial reduction of chromium from the hexavalent to the divalent state. Geochem Cosmochim Acta 71(3):557-565

Dermou E, Vayenas DV (2008) Biological Cr(VI) reduction in a trickling filter under continuous operation with recirculation. J Chem Technol Biotechnol 83(6):871-877

Desai C, Jain K, Madamwar D (2008) Evaluation of in vitro Cr(VI) reduction potential in cytosolic extracts of three indigenous Bacillus sp. isolated from $\mathrm{Cr}(\mathrm{VI})$ polluted industrial landfill. Bioresour Technol 99(14):6059-6069

Elangovan R, Philip L, Chandraraj K (2010) Hexavalent chromium reduction by free and immobilized cell-free extract of Arthrobacter rhombi-RE. Appl Biochem Biotechnol 160(1):81-97

Garcia J, Cadena G, Gonzalez R, Cervantes C (1997) Purification and characterization of a chromate reductase from Bacillus. Rev Latinoam Microb 39(1-2):73-81

Gibb HJ, Lees PS, Pinsky FP, Rooney BC (2000a) Clinical findings of irritation among chromium chemical production workers. Am J Ind Med 38:127-131

Gibb HJ, Lees PS, Pinsky FP, Rooney BC (2000b) Lung cancer among workers in chromium chemical production. Am J Ind Med 38:115-126

Gonzalez CF, Ackerley DF, Lynch SV, Matin A (2005) ChrR, a soluble Quinone reductases of Pseudomonas putida that defends against $\mathrm{H}_{2} \mathrm{O}_{2}$. J Biol Chem 280(24):22590-22595

He Z, Gao F, Sha T, Hu Y, He C (2009) Isolation and characterization of a $\mathrm{Cr}(\mathrm{VI})$ reduction Ochrobactrum sp. strain CSCr-3 from chromium landfill. J Hazard Mater 163(2-3):869-873

Henne KL, Nakatsu CH, Thompson DK, Konopka AE (2009) Highlevel chromate resistance in Arthrobacter sp. strain FB24 requires previously uncharacterized accessory genes. BMC Microbiol 9:199

Horton RN, Apel WA, Thompson VS, Sheridan PP (2006) Low temperature reduction of hexavalent chromium by a microbial consortium and a novel strain of Arthrobacter aurescens. BMC Microbiol 6:5

Kang SY, Lee JU, Kim KW (2006) Biosorption of Cr(III) and Cr(VI) onto the cell surface of Pseudomonas aeruginosa. Biochem Eng J 36(1):54-58

Kaszycki P, Fedorovych D, Ksheminska H, Babyak L, Wojcik D, Koloczek (2004) Chromium accumulation by living yeast at various environmental conditions. Microbiol Res 159:11-17

Katz SA, Salem H (1994) The biological and environmental chemistry of chromium. The toxicology of chromium and its compound. VCH Publishers, Inc, New York

Konovalova VV, Dmytrenko GM, Nigmatullin RR, Bryk MT, Gvozdyak PI (2003) Chromium (VI) reduction in a membrane bioreactor with immobilized Pseudomonas cells. Enzyme Microb Technol 33:899-907

Krishnamurthy S, Wilkens MW (1994) Environmental chemistry of Cr. Northeast Geol 16(1):14-17

Law WM, Lau WN, Lo KL (2003) Removal of biocide pentachlorophenol in water system by the spent mushroom compost of Pleurotus pulmonarius. Chemosphere 52:1531-1537

Lee SE, Lee JU, Chon HT, Lee JS (2008) Reduction of Cr(VI) by indigenous bacteria in $\mathrm{Cr}$-contaminated sediment under aerobic condition. J Geochem Explor 96(2-3):144-147

Liu YG, Xu WH, Zeng GM, Li X, Gao H (2006) Cr (VI) reduction by Bacillus sp. isolated from chromium landfill. Process Biochem 41:1981-1986
Miranda AT, Gonzalez MV, Gonzalez G, Vargas E, Campos-Garcia J, Cervantes C (2009) Involvement of DNA helicases in chromate resistance by Pseudomonas aeruginosa PA01. Mut Res Fundam Mol Mech Mutagen 578(1-2):202-209

Morales-Barrera L, Cristiani-Urbina E (2005) Removal of hexavalent chromium by Trichoderma viride in an airlift bioreactor. Enzyme Microb Technol 40:107-113

Muter O, Patmalnieks A, Rapoport A (2001) Interactions of the yeast Candida utilis and $\mathrm{Cr}$ (VI): metal reduction and its distribution in the cell and medium. Process Biochem 36:963-970

Ohtake H, Silver S (1994) Bacterial detoxification of toxic chromate. In: Chaudry GR (ed) Biological degradation and bioremediation of toxic chemicals. Chapman and Hall, London

Opperman DJ, Heerden V (2007) Aerobic Cr(VI) reduction by Thermus scotoductus strain SA-01. J Appl Microbiol 103(5): 1907-1913

Opperman DJ, Heerden V (2008) A membrane associated protein with $\mathrm{Cr}(\mathrm{VI})$ - reducing activity from Thermus scotoductus. FEMS Microbiol Lett 280(2):210-218

Opperman DJ, Piater LA, Heerden V (2008) A novel chromate reductase from Thermus scotoductus SA-01 related to old yellow enzyme. J Baceriol 190(8):3076-3082

Orozco AMF, Contreros EM, Zaritsky NE (2010) Cr(VI) reduction capacity of activated sludge as affected by nitrogen and carbon sources, microbial acclimation and cell multiplication. J Hazard Mater 176(1-3):657-665

Pal N (1997) Reduction of hexavalent chromium to trivalent chromium by Phanerochaete chryosporium. In situ and on-site bioremediation, vol 1. Batelle Press, OH, pp 511-517

Pal A, Paul AK (2004) Aerobic chromate reduction by chromium resistant bacteria isolated from serpentine soil. Microbiol Res 159:347-354

Pattanapipitpaisal P, Brown NL, Macaskie LE (2001) Chromate reduction and $16 \mathrm{~S}$ rRNA identification of bacteria isolated from a $\mathrm{Cr}(\mathrm{VI})$ contaminated site. Appl Microbiol Biotechnol 57(1-2):257-261

Pena-Castro JM, Martinez-Jeronimo F, Esparza-Garcia F, CaniresVillanueva RO (2004) Heavy metals removal by the microalga Scenedesmus incrassatulus in continuous cultures. Bioresour Technol 94:219-222

Pesti M, Gazdag Z, Belagyi J (2000) In-vivo interaction of trivalent chromium with yeast plasma membrane as revealed by EPR spectroscopy. FEMS Microbiol Lett 182:375-380

Poopal AC, Laxman RS (2009a) Chromate reduction by PVA alginate immobilized Streptomyces griseus in a bioreactor. Biotechnol Lett 31(1):71-76

Poopal AC, Laxman RS (2009b) Studies on biological reduction of chromate by Streptomyces griseus. J Hazard Mater 169(1-3): 539-549

Puzon GJ, Peterson JN, Roberts AJ, Kramer DM, Xun L (2002) A bacterial flavin reductase system reduces chromate to a soluble chromium(III)-NAD ${ }^{+}$complex. Biochem Biophys Res Commun 294:76-81

Puzon GJ, Robert AG, Kramer DM, Xun L (2005) Formation of soluble organo-Cr(III) complexes after chromate reduction in the presence of cellular organics. Environ Sci Technol 39(8):2811-2817

Puzon GJ, Xun L, Tokala R, Zhang Z, Clark S, Peyton B, Yonge D (2008) Production and fate of organo-Cr(III) complexes from microbial reduction of chromate: evidence and implications. AIHS-AISH Publ 324:420-427

Ramirez-Ramirez R, Calvo-Mendez C, Avila-Rodriguez M, Lappe P, Ulloa M, Vazquez-Juarez R (2004) Cr(VI) reduction in chromium resistant strain of Candida maltosa isolated from the leather industry. Antonie van Leeuwenhook 85(1):63-68

Renuga G, Lakshminarayan S, Babu A, Arumugam KR (2008) Purification of chromate reductase and their bioremediation potential. Pollut Res 27(1):129-136 
Romanenko VI, Korenkov VN (1977) A pure culture of bacterial cells assimilating chromates and bichromates as hydrogen acceptors when grown under anaerobic conditions. Mikrobiologiya 46:414-417

Sarangi A, Krishnan C (2008) Comparison of in-vitro Cr(VI) reduction by CFEs of chromate resistant bacteria isolated from chromate contaminated soil. Bioresour Technol 99(10): 4130-4137

Saxena DK, Murthy RC, Jain VK, Chandra SV (1990) Fetoplacental-maternal uptake of hexavalent chromium administered orally in rats and mice. Bull Environ Contam Toxicol 45:430 435

Silver S, Schottel J, Weiss A (2001) Bacterial resistance to toxic metals determined by extrachromosomal $\mathrm{R}$ factors. Int Biodeterior Biodegrad 48(1-4):263-281

Srinath T, Verma T, Ramteke PW (2002) Cr(VI) biosorption and bioaccumulation by chromate resistant bacteria. Chemosphere 48:427-435

Stewart DI, Burke IT, Mortimer RJG (2007) Stimulation of microbially mediated chromate reduction in alkaline soil-water systems. Geomicrobiol J 24(7-8):655-669

Stewart DI, Burke IT, Hughes-Berry DV, Whittleston RA (2010) Microbially mediated chromate reduction in soil contaminated by highly alkaline leachate from chromium containing waste. Ecol Eng 36(2):211-221

Tarley CRT, Arruda MAZ (2004) Biosorption of heavy metals using rice milling by-products: characterization and application for removal of metals from aqueous effluents. Chemosphere 54(7):987-995

Tewari N, Vasudevan P, Guha BK (2005) Study on biosorption of $\mathrm{Cr}(\mathrm{VI})$ by Mucor hiemalis. Biochem Eng J 23:185-192

Turpeinen R, Kairesalo T, Haggblom MM (2004) Microbial community structure and activity in arsenic, chromium and copper contaminated soils. FEMS Microbiol Ecol 47(1):39-50

Ucun H, Bayhan YK, Kaya Y (2002) Biosorption of chromium(VI) from aqueous solution by cone biomass of Pinus sylvestris. Bioresour Technol 85:155-158

Vatsouria A, Vainshtein M, Kuschk P, Wiessner A, Kosolapov D, Kaestner M (2005) Anaerobic co-reduction of chromate and nitrate by bacterial cultures of Staphylococcus epidermidis L-02. J Ind Microbiol Biotechnol 32(9):409-414
Verma T, Garg SK, Ramteke PW (2009) Genetic correlation between chromium resistance and reduction in Bacillus brevis isolated from tannery effluent. J Appl Microbiol 107(5):1425-1432

Verma T, Ramteke PW, Garg SK (2004) Occurrence of chromium resistant thermotolerant coliforms in tannery effluent. Indian $\mathrm{J}$ Exp Biol 42(11):1112-1116

Viamajala S, Peyton BM, Gerlach R, Sivaswamy V, Apel WA, Peterson JN (2008) Permeable reactive biobarriers for in situ $\mathrm{Cr}(\mathrm{VI})$ reduction: bench scale tests using Cellulomonas sp. strain ES6. Biotechnol Bioeng 101(6):1150-1162

Viamajala S, Smith WA, Sani RK, Apel WA, Peterson JN, Neal AL, Roberto FF, Peyton BM (2007) Isolation and characterization of $\mathrm{Cr}(\mathrm{VI})$ reducing Cellulomonas sp. from subsurface soils: implications for long-term chromate reduction. Bioresour Technol 98(3):612-622

Villegas LB, Fernandez PM, Amoroso MJ, De Figueroa LIC (2008) Chromate removal by yeasts isolated from sediment of a tanning factory and a mine site in Argentina. Biometals 21(5):591-600

Viti C, Mini A, Ranalli G, Lustrato G, Giovannetti L (2006) Response of microbial communities to different doses of chromate in soil microcosms. Appl Soil Ecol 34(2-3):125-139

Viti C, Pace A, Giovannetti L (2003) Characterization of Cr(VI) resistant bacteria isolated from chromium-contaminated soil by tannery activity. Curr Microbiol 46(1):1-5

Wang YT (2000) Microbial reduction of chromate. In: Loveley DR (ed) Environmental microbe-metal interactions. American Society for Microbiology Press, Washington DC

Wani R, Kodam KM, Gawai KR, Dhakephalkar PK (2007) Chromate reduction by Burkholderia cepacia MCMB-821, isolated from the pristine habitat of alkaline crater lake. Appl Microbiol Biotechnol 75(3):627-632

Yang C, Cheng Y, Ma X, Zhu Y, Wang C (2007) Surface-mediated chromate-resistant mechanism of Enterobacter cloacae bacteria investigated by atomic force microscopy. Langmuir 23(8): $4480-4485$

Yang J, He M, Wang G (2009) Removal of toxic chromate using free and immobilized $\mathrm{Cr}(\mathrm{VI})$ reducing bacterial cells of Intrasporangium sp Q5-1. World J Microbiol Biotechnol 25(9):1579-1587

Zhu WJ, Long HZ, Yang ZH, Chai LY (2008) Bio-reduction of $\mathrm{Cr}(\mathrm{VI})$ by Leucobacter and element analysis of reduction products. J Cent South Univ Sci Technol 39(3):443-447 